\title{
Böbrek Transplantı Alıcılarında Görülen İnfeksiyonların Sıklığı ve Özellikleri Böbrek transplantasyonunda infeksiyonlar
}

\author{
Clinical Features and Frequency of Posttransplant Infections In Kidney Transplant \\ Recipients Infections in Kidney Transplant Recipients
}

Aslı Karadeniz', Haluk Eraksoy², Arif Atahan Çağatay², Halil Yazıcl', Halit Özsüt ${ }^{2}$, Uluğ Eldegez ${ }^{4}$, Mehmet Şükrü Sever3

'Maltepe Üniversitesi Tıp Fakültesi, İnfeksiyon Hastalıkları ve Klinik Mikrobiyoloji

Anabilim Dalı, İstanbul, Türkiye

¿istanbul Üniversitesi Tıp Fakültesi, İnfeksiyon Hastalıkları ve Klinik Mikrobiyoloji Anabilim Dalı, İstanbul, Türkiye

3istanbul Üniversitesi Tıp Fakültesi, Iç Hastalıkları Anabilim Dalı, Nefroloji Bilim Dalı ìstanbul, Türkiye

"ístanbul Üniversitesi Tıp Fakültesi, Genel Cerrahi Anabilim Dalı, İstanbul, Türkiye

\section{ÖZET}

Amaç: Böbrek transplantasyonu sonrası infeksiyöz komplikasyonlar önemli morbidite nedenidir. Çalışmada böbrek transplantasyonu yapılan hastalarda transplantasyon sonrası gelişen infeksiyonları ve özelliklerini incelemek amaçlanmıştır.

Materyal ve Metodlar: Çalışmamızda, İstanbul Tıp Fakültesi Hastanesinde, Ocak 2005-Aralık 2006 tarihleri arasında transplantasyon yapılan 91 hasta (71'i canlı, 20'si kadavradan), transplantasyondan sonra ortalama $23,4 \pm 7,4$ ay süreyle takip edildi ve retrospektif olarak değerlendirildi.

Bulgular: Böbrek transplantı alıcılarında saptanan infeksiyon oranı \% 48,4'dir. Kadavradan organ alan hastalarda yoğun immünosüpresif tedavi, geniş spektrumlu ve uzun süreli uygulanan perioperatif profilaksi ve idrar sondasının uzun süre kalması gibi infeksiyon riski taşıyan uygulamalar dikkat çekmiş ve bu hastalarda infeksiyon sıklığı (\% 70), canlıdan organ alanlara (\% 42,25) göre daha yüksek bulunmuştur. Infeksiyon zaman takvimine göre değerlendirildiğinde, posttransplantasyon dönemde en fazla infeksiyon 1-6 ay arası dönemde (\% 43) görülmüştür. Üriner sistem infeksiyonları tüm dönemlerde en sık $(\% 68,6)$ saptanan infeksiyon olup bunu pnömoni (\% 14) ve cerrahi alan infeksiyonları (\% 9.3) izlemiştir. Sitomegalovirus infeksiyonu $(n=2)$, herpes zoster $(n=2)$, kandidemi $(n=1)$ ve tüberkülöz epididimoorşit $(n=1)$ diğer nadir infeksiyonlardır. Bakteriyel infeksiyonlar en sık saptanırken, Pseudomonas aeruginosa ve Escherichia coli en sık etkenlerdir.

Sonuç: Böbrek transplantasyonunda immünosüpresyon tedavisi ve cerrahi tekniklerde elde edilen tüm gelişmelere rağmen, infeksiyonlar hâlâ önemli bir problemdir ve transplantasyon öncesi değerlendirme ve transplantasyon sonrası koruma ve kontrol önlemlerine uymak en iyi yaklaşım olacaktır.

Anahtar kelimeler: böbrek, transplantasyon, infeksiyon
Illetişim: Aslı Karadeniz

Maltepe Üniversitesi Tıp Fakültesi, İnfeksiyon Hastalıkları ve Klinik Mikrobiyoloji Anabilim Dalı, İstanbul, Türkiye e-mail: asli.karadeniz@maltepe.edu.tr

\section{SUMMARY}

Aim: Infectious complications after renal transplantation are associated with significant morbidity. We aimed to determine the clinical features and frequency of posttransplant infectious complications.

Material and Methods: We evaluated 91 patients (71 living related donors, 20 cadaveric) who were transplanted between January 2005 and December 2006; (mean 23.4 7.4 months), at istanbul Medical Faculty, retrospectively.

Results: The overall incidence of infections at renal transplant recipients was $48.4 \%$. Prolonged urinary bladder catheterization, intense immunosuppressive therapy, prolonged perioperative prophylaxis with broad-spectrum antibiotics were recognized in cadaveric donor transplant recipients and the infection rate among these patients $(70 \%)$ was higher than the recipients from living related donor (42.25\%). According to the time period, most of the infections (43\%) were seen at posttransplant 1-6 months period. Urinary tract infections (68.6\%) were the most common infections after renal transplantation for all periods, followed by pneumoniae $(14 \%)$ and surgical site infections (9.3\%). Cytomegalovirus infections $(n=2)$, herpes zoster $(n=2)$, candidemia $(n=1)$ and tuberculous epididymoorchitis $(n=1)$ were other rare infections. As most of the infections were bacterial; Pseudomonas aeruginosa and Escherichia coli were the most frequent causes of these infections.

Conclusions: Although advances have been made in surgical techniques and immunosupression for renal transplantation, infections continue to be a significant problem and pretransplant evolution and posttransplant prevention and control measures will be the best management for these patients.

Keywords: kidney, transplantation, infection 


\section{Giriş}

Böbrek transplantasyonu, son dönem böbrek hastalıklarının tedavisinde başarılı bir tedavi modelidir. Organ korunması, cerrahi teknikler, rejeksiyon tedavileri ve postoperatif bakımda kaydedilen gelişmeler, transplantasyon sonrası infeksiyon profilaksisi ve tedavisi için daha etkili antibiyotiklerin kullanımı bu başarıya katkıda bulunmuştur $(1,2)$. Özellikle yeni immünosüpresif ajanların kullanıma girmesi, organ transplantasyonu sonrası gelişen infeksiyonların spektrumunda değişikliklere neden olmuştur. Transplantasyon sonrası görülen infeksiyonun tipi; özgül etyoloji, kolaylaştırıcı faktörler ve transplantasyonun yapıldığı merkeze göre değişiklikler gösterir (1). Tüm gelişmelere rağmen, organ transplantasyonu sonrası görülen infeksiyöz komplikasyonlar, morbidite ve mortalitenin başlıca nedenlerinden biri olmaya devam etmektedir (1-5).

Organ transplantasyonu sonrası gelişen infeksiyonlar; cerrahi faktörler, immünosüpresyon düzeyi ve çevresel temasın etkisine göre, klasik olarak 3 zaman diliminde incelenir; transplant alıcıları farklı zaman dilimlerinde farklı patojenlerdenetkilenmektedir. Transplantasyondan sonraki ilk ayda; transplantasyondan önce var olan ve eradike edilememiş, transplantasyondan sonra immünosüpresyonla alevlenebilen infeksiyonlar, alıcıya allogreftle taşınabilen infeksiyonlar ve özellikle benzer cerrahi işlem uygulanan hastalarda görülen infeksiyonlar sıktır. 1-6 ay arasındaki dönemde immünomodülatör viruslar ile ve kısmen bu virusların da katkısıla özellikle immünosüpresyon düzeyinin artması sonucu fırsatçı patojenlerin etken olduğu infeksiyonlar sıktır. Transplant alıııları, 6 aydan sonraki dönemde en sık toplum kaynaklı infeksiyonlardan etkilenir (5-7).

Bu çalışmada, canlı donör ve kadavradan böbrek transplantasyonu yapılan hastalarda postoperatif dönemde gelişen infeksiyonların özelliklerini incelemek amaçlanmıştır.

\section{MATERYAL VE METODLAR}

İstanbul Tıp Fakültesi Hastanesi'nde Ocak 2005Aralık 2006 tarihleri arasında, art arda böbrek transplantasyonu yapılan toplam 91 hasta (71 hasta canlıdan, 20 hasta kadavradan) retrospektif olarak değerlendirilmiştir. Hastaların epidemiyolojik verileri, donör kaynakları (canlı veya kadavra), aldıkları tedavi rejimleri, operasyon sonrası hastanede yatış süresi ve idrar sondasının kaldığı süre gibi infeksiyon riski yaratan diğer özellikleri, transplantasyondan sonra geçirdikleri infeksiyonlar kaydedilmiştir. Transplantasyondan sonra hastalarda saptanan infeksiyonlar görüldükleri zamana göre; ilk 1 aylık (erken perioperatif), 1-6 ay arası ve 6 aydan sonraki (geç) dönemde görülen infeksiyonlar olarak 3 gruba ayrılarak incelenmiştir. İnfeksiyonların tanısı, zamanı, infeksiyon sırasında hastanın aldığı tedaviler, atak sırasında biyokimyasal değerleri (kan sayımı, BUN, kreatinin, ürik asid, protein, albumin, sedimantasyon ve C-reaktif protein), infeksiyon etkeni, hastaların infeksiyon sırasında böbrek fonksiyonları, yoğun bakım ihtiyacının olup olmadığı ve tedaviye yanıtları kaydedilmiştir.

Canlı ve kadavra donörden transplantasyon yapılan hastalardan elde edilen sonuçların karşılaştıııması için, istatistiksel incelemelerde, SPSS 11.5 yöntemi ile, $x^{2}$ testi veya Fisher'ın kesin testi ve Student t testi kullanılmıştır. Sonuçlar; $p$ değeri < 0.05 için anlamlı kabul edilmiştir.

\section{BULGULAR}

Böbrek transplantasyonu uygulanan 91 hastanın altta yatan hastalıkları da içeren epidemiyolojik özellikleri Tablo 1'de özetlenmiştir. İzlem sırasında 91 hastadan ikisi (medikal ve cerrahi komplikasyonlar gelişen bir hasta pnömoni tablosu sonrası, diğeri kardiyak arrest nedeniyle) kaybedilmiştir. Her iki hasta da, kadavradan transplantasyon yapılan hastalardır (Mortalite; canlı donörden organ alanlarda 0/71, kadavradan organ alanlarda 2/20; $p=0.046$ ).

Hastalara kortikosteroid, mikofenolik asid (MYF), mikofenolat mofetil, siklosporin, takrolimus veya sirolimusu içeren $3^{\prime}$ lü kombine tedavi uygulanmış olup, kadavradan nakil gerçekleştirilen sadece 1 hasta, MYF ve streoid başlangıç tedavisi ile izlenmiştir. Takip sırasında istenmeyen etkiler nedeniyle, kadavradan transplantasyon yapılan 11, canlı donörden böbrek transplantasyonu yapılan 9 hastada olmak üzere toplam 20 hastada (\% 22) immünosüpresif tedavide değişiklik yapılmıştır $(11 / 20,9 / 71 ; p<0.0001)$.

Perioperatif antibakteriyel profilakside; canlı donörden transplantasyon yapılan hastalarda (1 hastada penisilin alerjisi nedeniyle siprofloksasin uygulanması hariç) sefuroksim sodyum (ortalama $6 \pm 1.5$ gün); kadavradan nakil yapılan hastalara sefoperazon-sulbaktam ve metronidazol (ortalama $7 \pm 2.5$ gün süreyle) uygulandığı görülmüş; kadavradan transplantasyon yapılan hastaların 3'ünde, donörde (hemokültürde) metisiline dirençli stafilokok üremesi saptanmış olduğundan profilaksiye vankomisin eklenmiştir. Böbrek transplantasyon protokolüne uygun şekilde, antiviral ve antifungal profilaksi, ve 1 yıla dek kotrimoksazol 
profilaksisi uygulanmıştır, ayrıca PPD sonucuna göre gerek olduğunda anti-tüberküloz profilaksi ve 2 hastada kronik hepatit B infeksiyonu nedeniyle lamivudin; 1 hastada donörün HBsAg' nin pozitif olması nedeniyle immünglobülin ile lamivudin uygulanmıştır.

Tablo 1. Transplant Alıılarının Donör Kaynaklarına Göre Özellikleri

\begin{tabular}{|c|c|c|}
\hline & Canlıdan Nakil Yapılanlar & Kadavradan Nakil Yapllanlar \\
\hline Hasta Sayısı & 71 & 20 \\
\hline \multicolumn{3}{|l|}{ Cinsiyet } \\
\hline Kadın & 18 & 8 \\
\hline Erkek & 53 & 12 \\
\hline Ortalama Yaș* $(p=0.002)$ & $32.54 \pm 1.15 \mathrm{y} 1 \mathrm{l}$ & $40.5 \pm 2.12$ yil \\
\hline Hastanede Yatuş Süresi* & $25.86 \pm 2.07$ gün & $39.65 \pm 9.25$ gün \\
\hline$(p=0.042)$ & (7-96 gün) & (12-197 gün) \\
\hline \multicolumn{3}{|l|}{ Altta Yatan Hastalık } \\
\hline KGN & 16 & 5 \\
\hline Primeri bilinmeyen SDBY & 16 & 4 \\
\hline IgAnefropatisi & 7 & 1 \\
\hline KPN & 5 & 1 \\
\hline Hipertansif nefropati & 6 & 6 \\
\hline Primernefroskleroz & 2 & - \\
\hline Diyabetiknefroskleroz & 2 & - \\
\hline Difüz proliferatif GN & 1 & - \\
\hline FSGS & 1 & - \\
\hline Polikistik böbrek & 2 & - \\
\hline Lupus nefriti & - & 1 \\
\hline ÜPJ darliğ1 & 3 & - \\
\hline VUR & 5 & 1 \\
\hline Amiloidoz & 4 & 1 \\
\hline Kresentik GN & 1 & - \\
\hline \multicolumn{3}{|l|}{ Transplantasyona Dek } \\
\hline Takip Edilme Süresi & $5.83 \pm 6.51 \mathrm{yil}$ & $7.6 \pm 3.91 \mathrm{yll}$ \\
\hline \multicolumn{3}{|l|}{ Diyaliz Yolu } \\
\hline Hemodiyaliz & 51 & 17 \\
\hline Peniton diyalizi & 8 & 3 \\
\hline Diyaliz yapilmayan & 12 & - \\
\hline Diyaliz Süresi* $(p<0.0001)$ & 23.39 ay & 64.4 ay \\
\hline \multicolumn{3}{|l|}{ Transplantasyon Sonrasi } \\
\hline İzlem Süresi & $22.74 \pm 0.81$ ay & $25.7 \pm 2$ ay \\
\hline \multicolumn{3}{|l|}{ Transplantasyon Sonrası } \\
\hline $\begin{array}{l}\text { Sonda Kalı̣̦ Süresi * } \\
(p<0.0001)\end{array}$ & 7 gün & 16.5 gün \\
\hline
\end{tabular}

KGN: Kronik glomerülonefrit, SDBY: Son dönem böbrek yetmezliği, KPN: Kronik pyelonefrit, GN: Glomerülonefrit, FSGS: Fokal sklerozan glomerüloskleroz, FMF: Ailevi akdeniz ateşi, ÜPJ:

Üreteropelvik bileşke darlığı, VUR: Veziküloüretral reflü

* iki grup arasındaki fark istatistiksel olarak anlamlıdır.

\section{İnfeksiyöz Komplikasyonlar}

Böbrek transplantasyonu yapılan 91 hasta değerlendirildiğinde, 44 hastada infeksiyon (infeksiyon oranı \% 48.4 olarak) saptanmıştır. Böbrek transplantı alıcılarında infeksiyonlar donör kaynağına göre değerlendirildiğinde; kadavradan tranplantasyon yapılan hastalarda infeksiyon oranı \% 70 (14/20), canlı donörden transplantasyon yapılanlarda $\% 42.25$ (30/71) saptanmıştır $(p=0.042)$. Infeksiyon geçiren hastalarda, birden fazla infeksiyon geçirme sıklığı, kadavradan transplantasyon yapılan grupta \% 85.81 (12/14), canlıdan organ alan hastalarda \% 36.7 (11/30) olarak hesaplanmıştır ( $p=0.003)$.

Üriner sistem infeksiyonu (Üsi) böbrek transplantasyonu yapılan hastalarda \% 68.6 (59/86) oranla en sık saptanan infeksiyondur. Donör kaynağına göre değerlendirildiğinde, Üsi' nin tüm infeksiyonlara oranı, kadavradan transplantasyon yapılan hastalarda \%69.5 (25/36); canlıdan transplantasyon yapılan hastalarda \% 68 (34/50)'dir. Üsi geçiren hastalarda; tekrarlayan Üsi oranı ise \% 44.1 (15/34)'dir. Bu hastalarda, donör kaynağına göre tekrarlayan Üsi oranları; kadavradan organ alan hastalarda \% 66.7 (8/12) ve canlıdan nakil yapılanlarda \% 31.8 (7/22) olarak hesaplanmıştır. Pnömoni \% $14(12 / 86)$ oranla en sık ikinci; cerrahi alan infeksiyonları \% 9.3 (8/86) oranla en sık üçüncü infeksiyon tablosu olmuştur. Bu hastalarda görülen infeksiyonların zamana göre dağılımı tablo 2' de özetlenmiştir.

Tablo 2. Böbrek Transplantı Alıcılarında Görülen İnfeksiyonlar

\begin{tabular}{|l|c|c|c|}
\hline & $\begin{array}{c}\text { 0-1ayda Görülen } \\
\text { Infeksivonlar }\end{array}$ & $\begin{array}{c}\text { 1-6 Ayda Görülen } \\
\text { Infeksivonlar }\end{array}$ & $\begin{array}{c}\text { 6 aydan Sonra Görülen } \\
\text { Infeksiyonlar }\end{array}$ \\
\hline ÜSI & 25 & 22 & 12 \\
\hline Pnömoni & 1 & 9 & 2 \\
\hline Cerrahi Alan & 4 & 4 & - \\
\hline Fungemi & - & 1 & - \\
\hline Tromboflebit & - & 1 & 2 \\
\hline CMV İnfeksiyonu & - & - & 1 \\
\hline Herres zoster & - & - & 2 \\
\hline Tbc epididimoorsit & - & - & \\
\hline
\end{tabular}

Böbrek transplantasyonu sonrası infeksiyon geçiren 44 hastada, infeksiyonlar sırasındaki laboratuvar bulguları Tablo3'te sunulmuştur. Hastalarda, infeksiyon sırasında, \%57'sinde böbrek fonksiyonlarının bozulduğu ve \%14'ünde yoğun bakım ihtiyacı olduğu gözlenmiştir. Böbrek fonksiyonlarında bozulma; canlıdan organ alan hastalardaki infeksiyonlarda \%46 (50 infeksiyon atağının 23'ünde); kadavradan organ alan hastalardakilerde \%72.2 (36 infeksiyon atağının 26'sında) oranında saptanmıştır $(p=0.013)$. Yoğun bakım ihtiyacı ise, canlıdan organ alan hastalardaki infeksiyonlarda \%6 (3/50); kadavradan organ alan hastalarda \%25 (9/36) olarak saptanmıştır $(p=0.025)$. 
Tablo 3. Infeksiyon Sırasında Laboratuvar Değerleri

\begin{tabular}{lccc}
\hline Infeksiyon Sirasmdaki & \multicolumn{2}{c}{ Donör Kaynağ1 } & $p$ \\
Değer & Canl & Kadavra & \\
\hline Lökosit $\left(/ \mathrm{mm}^{3}\right)$ & 14736 & 11752 & 0.099 \\
\hline Nötrofil $\left(/ \mathrm{mm}^{3}\right)$ & 12068 & 10511 & 0.348 \\
\hline Trombosit $\left(/ \mathrm{mm}^{3}\right)$ & 274800 & 198444 & $<\mathbf{0 . 0 0 1}$ \\
\hline Hb(g/d1) & 11 & 9.7 & $\mathbf{0 . 0 0 6}$ \\
\hline Hct & 32.5 & 28 & $\mathbf{0 . 0 0 4}$ \\
\hline BUN(mg/dl) & 25.6 & 44.7 & $\mathbf{0 . 0 0 2}$ \\
\hline Kreatinin $(\mathrm{mg} / \mathrm{dl})$ & 1.6 & 2.7 & $\mathbf{0 . 0 0 3}$ \\
\hline Urik asid(mg/d1) & 5.3 & 5.8 & 0.402 \\
\hline AST (U/L) & 17 & 29 & $\mathbf{0 . 0 3 6}$ \\
\hline ALT (U/L) & 26 & 44 & $\mathbf{0 . 0 1 7}$ \\
\hline Total protein (g/dl) & 6.4 & 6 & $\mathbf{0 . 0 1 5}$ \\
\hline Albumin $(\mathrm{g} / \mathrm{dl})$ & 3.8 & 3.4 & $\mathbf{0 . 0 0 7}$ \\
\hline Sedim $(\mathrm{mm} /$ saat) & 46 & 71 & $\mathbf{0 . 0 0 1}$ \\
\hline CRP(mg/L) & 80 & 99 & 0.720 \\
\hline
\end{tabular}

Üsi'de en sık saptanan etkenler P.aeruginosa (\% 40.7) ve E.coli (\% 39) olmuştur. Diğer infeksiyon etkenleri arasında; enterokoklar (\% 10.2), K.pneumoniae (\% 8.5), Candida spp. (\% 3.4) ve MRSA (\% 1.7) saptanmıştır. Tekrarlayan Üsi atakları (15 hastada) değerlendirildiğinde; 12 hastada ataklardan aynı patojenin (yedi hastada E.coli; dört hastada P.aeruginosa ve bir hastada K.pneumoniae) sorumlu olduğu gözlenmiştir. Tekrarlayan infeksiyonlar geçiren hastaların \% 66.6' sı (10/15) ilk ataklarını 0-1 ay arasıda, erken dönemde geçirmiştir. Pnömoni ataklarının \% 50'sinde etken saptanamamış olup toplum kaynaklı bu infeksiyonlarda antibiyotik tedavisine yanıt alınmıştır. Infeksiyonların \%25'inde (3/12) etken olarak P.aeruginosa saptanmıştır. Pnömoni ataklarında etken olan diğer patojenler bir atakta P.jirovecii (1-6 ay arasında, canlıdan transplanasyon yapılan bir hastada); bir atakta MRSA (1-6 ay arasında kadavradan transplantasyon yapılan bir hastada) ve 1 atakta S.pneumoniae (6 aydan sonraki dönemde, kadavradan transplantasyon yapılan bir hastada) olarak saptanmış ve başarılla tedavi edilmiştir. Cerrahi alan infeksiyonları, bu hastalarda en sık saptanan üçüncü infeksiyon (\% 9.3; 8/86) olup \% 50'si, 0-1 ay arasındaki dönemde; canlıdan transplantasyon yapılan hastalarda gözlenmiştir. Bu dönemdeki saptanan dört atağın üçünde MRKNS, MRSA, P.aeruginosa etkendir; bir atakta etken saptanmamıştır.

Kadavradan transplantasyon yapılan bir hastada, 1-6 ay arası dönemde kandidemi tanısı, (C.krusei), canlıdan transplantasyon yapılan iki hastada; posttransplant 6 . aydan sonraki dönemde, kanda CMV antijeni ve/veya CMV DNA pozitifliği ile CMV infeksiyonu tanısı ; yine canlıdan transplantasyon yapılan bir hastada görülen tüberkülöz epididimoorşitte, aspirat kültüründe $\mathrm{M}$. tuberculosis üremiştir. İi hastada gözlenen herpes zoster infeksiyonlarında tanı klinik olarak konmuş ve bu infeksiyonlar 6 aydan sonraki dönemlerde kaydedilmiştir.

\section{TARTIŞMA}

Böbrek transplantasyonu son dönem kronik böbrek hastalıklarının tedavisinde diyalize kıyaslandığında hayat kalitesinde ve süresinde anlamlı artışa neden olan bir tedavi seçeneğidir. Tüm gelişmelere rağmen infeksiyonlar böbrek transplantı alıılarında önemli morbidite nedeni olmaya devam etmektedir $(2,8,9)$.

Çalışmamızda, böbrek transplantasyonu yapılan hastalarda infeksiyon önemli bir komplikasyon olarak karşımıza çıkmıştır. İfeksiyon oranları, kadavradan nakil yapılan grupta daha yüksek saptanmıştır. Bu duruma, kadavradan transplantasyon yapılan hastalarda, transplantasyondan önce diyaliz süresi daha uzun, immünosüpresif tedavinin daha yoğun, immünosüpresif tedavide değişiklik ihtiyacının daha fazla ve postoperatif dönemde hastanede yatış süresinin anlamlı olarak daha uzun olması ve perioperatif profilakside canlı donörden transplantasyon yapılan hastalara ikinci kuşak sefalosporin kullanılırken, kadavradan organ alan hastalara daha geniş sepktrumlu ve uzun süreli antibiyotik kullanımı infeksiyon riskine etki ettiği düşünülmüştür.

Kadavradan transplantasyon yapılan hastalarda postoperatif dönemde idrar sondası çok daha uzun süre kullanılmıştır. Literatürde donör kaynağına göre transplant alıcılarında komplikasyonların irdelendiği çalışmalar sınırlı olmakla beraber, kadavradan transplantasyon yapılan hastaların nozokomiyal infeksiyonlar açısından daha yüksek risk taşıdıkları (10) ve canlı donörden transplantasyon yapıldığında hem kısa hem de uzun dönem sonuçlarının daha iyi olduğu (4) bilinmektedir. Immünosüpresif tedavide yapılan değişiklikler, Üsi için bağımsız risk faktörüdür (10). Çalışmamızda kadavradan transplantasyon yapılan hastalarda infeksiyon oranlarının daha yüksek olması; infeksiyon gelişmesinde risk yaratan bu faktörlerle ilişkilidir. Özellikle bu grupta; uzun süreli ve geniş spektrumlu perioperatif antibiyotik profilaksisi ve idrar sondasının gereğinden çok daha uzun süre tutulması dikkat çeken uygulamalar olmuştur. İnfeksiyon kontrol önlemlerinin katı şekilde uygulandığı, venöz kateterlerin, dren ve sondaların erken çıkarıldığı, gereksiz ve geniş spektrumlu antibiyotiklerin kullanımından kaçınıldığı merkezlerde, infeksiyon oranlarının daha düşüktür (11). 
Böbrek transplantasyonu yapılan hastalarda, infeksiyonlarınzaman diliminedağılımları incelendiğinde infeksiyonların en fazla, 1-6 aylık dönemde geliştiği belirlenmiştir. Literatürde, transplantasyon sonrası infeksiyon sıklıkları için değişik veriler olmakla beraber, çoğunlukla infeksiyonlar ilk 1 aylık dönemde yoğun olarak gözlenir; 6 aydan sonraki dönemde azalmaktadır (12).

Çalışmamızda böbrek transplantasyonu yapılan hastalarda Üsi, \% 68.6 oranla en sık saptadığımız infeksiyondur, kadavradan nakil yapılan grupta daha yüksek oranda saptanmıştır. Üsi, böbrek transplantasyonu sonrası en sık karşılaşılan infeksiyon tipidir $(8,10,12-18)$ ve böbrek transplantı alıcılarında \%35-80 oranında Üsi gelişmektedir $(12,18)$. Donör kaynağına göre infeksiyöz komplikasyonların karşılaştırdığı çok fazla yayın bulunmamaktadır; ancak, özellikle kadavra kaynaklı organ kullanımı ile; greftte iskemik değişiklikler, üreterovezikal anastomoz seviyesinde mesaneden üreterlere reflüyü engelleyen koruyucu mekanizmanın bozulması ve üriner kateterlerin varlığı gibi faktörler transplantasyon sonrası Üsi riskini arttırmaktadır (2).

Üsitablolarındasaptanan ensıketkenler transplantasyon sonrası tüm dönemlerde P.aeruginosa ve E.coli'dir, infeksiyon etkenleri literatürdeki çalışmalarla benzerlik göstermektedir $(2,10,14,16,19,20)$. Çalışmamızda P.aeruginosa'nın transplantasyon sonrası tüm dönemlerde en sık Üsi etkenlerinden biri olduğu birkez daha gösterilmiştir. Üsi tanısı konan hastalarda; kan ve idrar kültürleri alındıktan sonra seçilecek ampirik tedavi P.aeruginosa'yı da kapsayan, Gram-negatif bakterilere yönelik antibiyotiklerden biri olmalıdır (16). Kotrimoksazol profilaksisi, böbrek transplantasyonu sonrası hem Üsi hem de bakteriyemi insidansını azaltmaktadır $(2,5,8,14)$. Çalışmamızda bakteriyel etkenlerin dışında sadece iki hastada, 1-6 ay arası dönemde Candida spp. ile Üsi gelişmiştir. Candida spp. ile Üsi oranı birimimizde diğer çalışmalara kıyasla daha düşüktür $(13,20)$ ve sıklıkla ilk iki ay içinde gözlendiğini belirten diğer yayınlardakine kıyaslandığında daha geç dönemde ortaya çıkmıştır (5).

Pnömoni; böbrek transplantı alıcılarında ikinci en sık infeksiyon olarak saptanmıştır; sıklık açısından diğer çalışmalardaki oranlarla benzerlik gösterir $(8,20)$. Çalışmamızda, erken (ilk 1 aylık) dönemde sadece bir hastada pnömoni saptanmış olup, P.aeruginosa'nın etken olduğu bu infeksiyon başarı ile tedavi edilmiştir. P.aeruginosa'nın etken olarak saptandığı diğer iki pnömoni tablosu 1-6 aylık dönemde kadavradan transplantasyon yapılan hastalarda gözlenmiş, bu hastalardan biri infeksiyonun 5. gününde kaybedilmiştir. Pnömoni transplant grubunda morbidite ve mortalitenin önemli nedenlerindendir (21). Böbrek transplant alıcılarında pnömoniye bağlı mortalite oranının, ilk ayda daha yüksek olmakla beraber, \%11 olduğunu bildiren yayınlarla kıyaslandığında (21), hastalarımızda bahsedilen oranlar daha düşüktür. Tüm pnömoni ataklarının \%75'i 1-6 ay arasında görülmüştür; ve çoğunluğu toplum kaynaklıdır. Bu dönemde canlıdan transplantasyon yapılan bir hastada saptanan P.jirovecii ile pnömoni tablosu transplantasyonun 73. gününde saptanmış, kotrimoksazol ile başarıyla tedavi edilmiştir. Yoğun immünosüpresif tedavi alan (indüksiyon tedavisi, rejeksiyon tedavisi alan ve immünosüpresif tedavide sık değişiklik yapılan) bu hastada kotrimoksazol profilaksisi altında infeksiyon gelişmesi dikkat çekicidir; ancak genel olarak postoperatif dönemde düşük doz kotrimoksazol ile oldukça etkin profilaksi sağlanmaktadır $(5,22)$.

Cerrahi alan infeksiyonları, çalışmamızda böbrek transplantı alıcılarında saptanan üçüncü en sık infeksiyondur. Gelişen cerrahi tekniklerle sıklığı azalmış olmakla birlikte hala böbrek transplantasyonu sonrası \% 4-11 oranında görülmektedir; sıklık ve etkenler açısından değerlendirildiğinde hastalarımızdaki sonuçlar, literatürde bildirilen oranlarla benzerlik göstermektedir $(8,10,18)$.

Çalışmada canlı donörden organ alan 2 hastada; transplantasyondan sonra geç dönemde bir dermatomla sınırlı herpes zoster gelişmiştir. Hastalar asiklovir ile başarıyla tedavi edilmiştir. Lokalize dermatomal reaktivasyonla oluşan herpes zosterin transplantasyon sonrası ilk 6 aydan sonra ortaya çıkar (4), hatta herpes zoster olarak ortaya çıkan VZV reaktivasyonunun bu dönemde sıkça görülen tek fırsatçı viral infeksiyondur (5) ve böbrek transplantı alıcılarında insidansı \% 3-10' dur (23). Bu hastalarda primer VZV infeksiyonuna bağlı mortalite ve herpes zosterin ciddi komplikasyonlarının insidansının yüksek olması nedeniyle, tüm adayların transplantasyondan önce taranması (5); ve seronegatif olan alıcıların aşılanması önerilir (24).

CMV infeksiyonu; canlı donörden organ alan iki hastada; geç dönemde saptanmıştır; hasta ve donörlerin seropozitif olduğu bu 2 tabloda, erken dönemde tanı konmuş; gansiklovir tedavisi ile başarı sağlanmıştır. Böbrek transplantı alıcılarında CMV hastalığının sıklığı değişik merkezlerde \% 8-32 arasındadır ve özellikle 1-6 ay arasında CMV, bu hastalarda en önemli fırsatçı infeksiyon etkenlerinden biridir. CMV'nin erken tespit edilmesi ile veya CMV için risk faktörleri olan hastalarda 
antiviral ajanlarla preemptif tedavi umut verici bir yaklaşımdır(5,8,12).

Verilerimizde sadece bir hastada M.tuberculosis infeksiyonu (tüberkülöz epididimoorşit) saptanmış olup; infeksiyon geç dönemde saptanmıştır; yoğun immünosüpresif tedavi aldığı saptanan hastanın dosyası incelendiğinde, tüm hastalarda bakılmış olan PPD deri testi değerine (dolayısıyla izoniazid profilaksisi gerekliliğine) ait veri saptanmamıştır. Böbrek transplantı alıcılarında M.tuberculosis infeksiyonu riski, klinik olarak anlamlı oranda yüksektir; bu infeksiyonlar transplantasyon sonrası her hangi bir zamanda oluşabilir (5). Genel popülasyonda bu infeksiyonlarda en sık tutulum pulmoner iken böbrek transplantı alıcılarında ekstrapulmoner tutulum daha sıktır (25).

Çalışmada; hastaların takip edildiği nispeten kısa sayılabilecek bu süreçte M.tuberculosis infeksiyonunun sadece bir hastada belirmesi, riskli hastalarda profilaksi uygulanmasına bağlanmıştır.

Hastalarda saptanan tek kan dolaşımı infeksiyonu; 1-6 ay arası dönemde kadavradan transplantasyon yapılan bir hastada kaydedilen kandidemi tablosudur ve flukonazol profilaksisi altındaki bu hastada saptanan etken C.krusei' dir. Geçirdiği infeksiyonlar nedeniyle uzun süre antibiyotik tedavisi alan hastada gelişen bu infeksiyon kaspofungin ile tedavi edilmiştir. Böbrek transplantasyonu yapılan hastalarda fungal infeksiyon oranları oldukça düşük olmakla birlikte; immünosüpresif tedavi, hastanede yatış süresinin uzun olması, yoğun antibiyotik kullanımı gibi $(1,6)$ bu hastada da saptanan faktörler risk yaratır.

Böbrektransplantıalıcılarındakitüminfeksiyonların klasik infeksiyon-zaman takvimine göre değerlendirilmesinde; bu hastalarda 0-1 ay arasında görülen infeksiyonlar (ÜSi, cerrahi alan infeksiyonları ve pnömoni) bu dönemdeki infeksiyonların \% 90'ından fazlasını oluşturduğu bilinen, immünosüprese olmayıp benzer cerrahi uygulanan hastalarda görülen infeksiyonlardır $(5,6,19)$. Bu dönemde görülen infeksiyonların \%10'undan az kısmını oluşturan; önceden var olan latent infeksiyonun immünosüpresyonla alevlenmesi veya alıcıya allogreftle taşınan infeksiyonlara hastalarımızda rastlanmamıştır. Yine asiklovir kullanımı ile insidansının azaldığı bilinen ve bu dönemde karşılaşılan tek viral infeksiyon olan seropozitif bireylerde HSV reaktivasyonu (5) hastalarımızda gözlenmemiştir.

1-6 ay arası dönemde ise, immünosüpresyonun 39 etkisiyle birlikte başlıca infeksiyonlar olarak beliren immünomodülatör virus infeksiyonlarına (herpesviruslar, HAV, HBV, HCV, HIV) hastalarımızda rastlanmamış; yine bu dönemde görülmesi beklenen fırsatçı mikroorganizmalarla infeksiyonlar çok nadir hastada saptanmış ve bazı hastalarda, alıcı veya donörde latent olan M.tuberculosis veya hepatit viruslarıyla bu dönemde de oluşabilecek infeksiyonlar $(5,6,19)$ gözlenmemiştir. Hastalarımızda bu dönemde görülen infeksiyonlar yine Üsi, pnömoni (sadece bir vaka P.jirovecii; diğerleri toplum kaynaklı veya nozokomiyal etkenlerle oluşmuş infeksiyonlar) ve kadavradan organ alan hastalarda, komplikasyonlar sonrası tekrarlanan cerrahi girişimler veya perioperatif profilaksinin uzun süre uygulanması nedeniyle bu dönemde görülen cerrahi alan infeksiyonları olmuştur. Bu tablo, klasik infeksiyon-zaman takviminden farklılık göstermiştir (19); cerrahi tekniklerde ve immünosüpresif tedavideki gelişmelerin yanı sıra, hastalarda ve donörlerde infeksiyonlara yönelik preoperatif değerlendirmenin iyi yapılması, fırsatçı mikroorganizmalara karşı profilaktik ilaçların dikkatli ve uygun şekilde kullanımı gibi faktörler bu durumda etkilidir.

Hastalarımızda, 6 aydan sonra oluşan infeksiyonlar değerlendirildiğinde infeksiyon-zaman takvimine uygun şekilde çoğu hastada Üsi, toplum kaynaklı pnömoni gibi toplumda görülene benzer infeksiyonlar saptanmıştır. Bu dönemde oluşan Üsi tablolarının yarısında etkenin P.aeruginosa olması, bu hastalarda Üsi tanısı konduğunda, ampirik tedavi yaklaşımında akılda bulundurulması gereken bir durumdur.

Böbrek transplantı alıcılarında, tüm gelişmelere rağmen infeksiyon önemli bir morbidite nedenidir. Bu hastalarda oluşan infeksiyonların özelliklerini, sıklıklarını, etkenlerini hatta risk faktörlerini değerlendiren uzun süreli ve geniş kapsamlı çalışmaların özellikle o transplantasyon birimindeki durumun farkında olmak için önemli ve gerekli olduğu düşünülmektedir.

\section{KAYNAKLAR}

1. Stitt NL. Infection in the Transplant Recipient. Organ Transplant 2003 (C) 2003 Medscape.

2. Villacian JS, Paya CV. Prevention of infections in solid organ transplant recipients. Tranpl Infect Dis 1999; 1: 50-64

3. Bloom RD, Goldberg LR, Wang AY. An overview of solid organ transplantation. Clin Chest Med 2005; 26(4): 529-43

4. Matas AJ, Payne WD, Sutherland DE, Humar A, Gruessner RW, Kandaswamy R et al. 2,500 living donor kidney transplants: a single-center experience. Ann 
Surg 2001; 234(2): 149-64

5. Patel R, Paya CV. Infections in solid-organ transplant recipients. Clin Microbiol Rev 1997; 10: 86-124

6. Prasad SA, Kasiske BL, Curtis JJ, Gober O, Rubin $\mathrm{RH}$, Woodle Es et al. Infectious complications posttransplantation 2005; http://www.medscape.com/ viewprogram/4392

7. Rubin RH, Ikonen T, Gummert JF, Morris RE. The therapeutic prescription for the organ transplant recipient: the linkage of immunosuppression and antimicrobial strategies. Tranpl Infect Dis 1999; 1: 2939

8. Pourmand G, Salem S, Mehrsai A, Taherimahmoudi $M$, Ebrahimi R, Pourmand MR. Infectious complications after kidney transplantation: a single-center experience. Transplant Infect Dis 2007; 9; 302-9

9. Ness D, Olsburg J. UTI in kidney transplant. World J Urol. 2020 Jan;38:81-8.

10. Dantas SR, Kuboyama RH, Mazzali M, Moretti ML. Nosocomial infections in renal transplant patients: risk factors and treatment implications associated with urinary tract and surgical site infections. J Hosp Infect 2006; 63: 117-23

11. Ferraresso M, Berardinelli L. Nosocomial infection in kidney transplant recipients: a retrospective analysis of a single-center experience. Transplant Proc 2005; 37: 2495-6

12. Charfeddine $K$, Zaghden S, Kharrat M, Kamoun K, Jarraya F, Hachicha J. Infectious complications in kidney transplant recipients: a single-center experience. Transplant Proc 2005; 37: 2823-5

13. Safdar N, Slattery WR, Knasinski V, Gangnon RE, Li $Z$, et al. Predictors and outcomes of candiduria in renal transplant recipients. Clin Infect Dis 2005; 40: 1413-21 14. Sharma M, Rani $S$, Johnson LB. Effect of time after transplantation on microbiology of urinary tract infections among renal transplant recipients. Transplant Infect Dis 2008; 10; 145-8

15. Trzeciak S, Sharer R, Piper D, Chan T, Kessler C, Dellinger $R$ et al. Infections and severe sepsis in solidorgan transplant patients admitted from a universitybased ED. Am J Emerg Med 2004; 22: 530-3

16. Munoz P. Management of urinary tract infections and lymphocele in renal transplant recipients. Clin Infect Dis 2001; 33: 53-7

17. Takai K, Aoki A, Suga A, Tollemar J, Wilczek HE, Naito $K$ et al. Urinary tract infections following renal transplantation. Transplant Proc 1998; 30: 3140-1

18. Veroux M, Giuffrida G, Corona D, Gagliano M, Scriffignano $V$, Vizcarra $D$ et al. Infective complications in renal allograft recipients: epidemiology and outcome. Transplant Proc 2008; 40:1873-6

19. Anonymous. Introduction to the guidelines
(Editorial). Am J Transplant 2004; 4: 6-9

20. Ljungman P, Griffiths P, Paya C. Definitions of cytomegalovirus infection and disease in transplant recipients. Clin Infect Dis 2002; 34(8):1094-7

21. Cervera C, Agusti C, Angeles Marcos M, Pumarola T, Cofan F, Navasa $M$ et al. Microbiologic features and outcome of pneumonia in transplanted patients. Diagn Microbiol Infect Dis 2006; 55: 47-54

22. Sinha S, Jha R, Narayan G, Bhaskar BV, Rayudu RS, Hemlatha $K$, et al. Pulmonary infections after kidney transplantation: impact of prophylaxis. Transplant Proc 2003; 35: 287-8

23. Gourishankar S, McDermid JC, Jhangri GS, Preiksaitis JK. Herpes zoster infection following solid organ transplantation: incidence, risk factors and outcomes in the current immunosuppressive era. Am J Transplant 2004; 4: 108-15

24. Avery RK, Michaels M. Update on immunizations in solid organ transplant recipients: what clinicians need to know. Am J Transplant 2008; 8: 9-14

25. Ergun I, Ekmekci Y, Sengul S, Kutlay S, Dede F, Canbakan $\mathrm{F}$ et al. Mycobacterium tuberculosis infection in renal transplant recipients. Transplant Proc 2006; 38: $1344-5$ 